\title{
Mobile Banking the Future to Rural Financial Inclusion: Case Study of Zimbabwe
}

\author{
Ian Ndlovu ${ }^{1}$ Mercy Ndlovu ${ }^{2}$ \\ ${ }^{1}$ Lecturer, Department of Banking, National University of Science and Technology (NUST), Zimbabwe \\ ${ }^{2}$ Former student, Department of Banking, National University of Science and Technology (NUST), Zimbabwe
}

\begin{abstract}
The vitality of technology utilisation by banks in establishing competitiveness in rural areas is unarguable. This paper provides primary information to guide banks in structuring their marketing strategies, quality improvements and business processes on the backdrop of rural milieus in order to achieve financial inclusion. The sample comprised of respondents drawn from various banks, agents of mobile operators, rural residents including farmers from irrigation schemes in Gwanda District. The hypothesis of study was that mobile money is reducing rural financial exclusion faster than traditional rural banking, microfinance and financial development aid. The majority of small scale rural business people were influenced to bank with banks which use advanced modern banking technologies and are partnering with mobile network operators because of convenient service and the reduction of trips made to urban centres for banking purposes. A lot of credit was given by rural dwellers to the Ecocash product of ECONET which enables small scale rural business people to undertake many low value money transfers as well as payments for their business activities. The study concludes that mobile banking has potential in reducing poverty by bringing into mainstream economic activity the previously excluded rural communities.
\end{abstract}

Key Words: mobile banking, financial inclusion, microfinance, poverty, mobile network operators

\section{Introduction}

E-banking has been viewed as a revolution in progress in the banking industry. For instance, twenty years ago, 70 percent of all consumer financial transactions went through a bank office with brick and mortar structures in the banking industry of emerging nations throughout the world. Today, less than 30 percent of the same consumer financial transactions run through a branch office or the lobby of a main bank office [1]. Ebanking allows companies to make new business contacts from different global business alliances, test new products and services, and make market research and other enquiries all at a minimal cost both financial and otherwise[1]. E-banking services currently available include online inquiry; e-payments, e-transfer, online 24/7 banking services greatly reduce the labor cost, extend the service edge, and increase the banking efficiency and effectiveness [2].

In recent years, mobile banking service is emerging as a new dimension of electronic banking [3]. Mobile banking (M-banking) is the use of wireless devices (cell phones, Personal Digital Assistant (PDA), and laptops) by customers to access the internet and conduct the online services at any time from any place. The earliest mobile banking services were offered over Short Message Service (SMS). With the introduction of the first primitive smart phones with Wireless Applications Protocol (WAP) support enabling the use of the mobile web in 1999, European banks started to offer mobile banking on this platform to their customers. M-banking is viewed as a powerful tool to complement regular e-banking with new developed services [4]. The mobile phone revolution is sweeping across India and has the potential to dramatically transform the lives of the nation's rural poor.

There is a distinction between additive and transformative models of mobile banking [5].

1. Additive models are those in which the mobile phone is merely another channel to an existing bank account;

2. Transformational models are those in which the financial product linked to the use of the phone is targeted at the unbanked, who are largely low income people.

Mobile banking has the potential to be transformational because:

1. It uses existing mobile communications infrastructure which already reaches unbanked people It may be driven by new players, such as telcos ${ }^{1}$ with different target markets from traditional banks

\footnotetext{
${ }^{1}$ Usually, deposit taking is the regulated preserve of banks only, but where this is not prohibited, telcos and other issuers of pre-paid balances can also become issuers of e-money
} 
2. It may harness the power of new distribution networks for cash transactions, such as airtime merchants, beyond the conventional merchant POS or ATM networks of banks.

3. It may be cheaper than conventional banking, if the offering is competitive.

An estimated eight million rural Indians who own mobile phones do not have access to banks. Full-scale commercial implementation of rural m-banking is complex ${ }^{2}$. Econet is set to deploy 500 EcoCash agents throughout Zimbabwe [6]. The company has also established partnerships with 200 post offices and 300 independent agents [6]. At the time of publication, other mobile banking operators had not disclosed details about how many agents they will employ.

Mobile banking offers an opportunity to serve the "unbanked": only 20 percent of African families have a bank account[7]. Unbanked people, by far the majority in most developing countries, are in fact a heterogeneous group, including people who may have adequate incomes but from an informal source, as well as poor, rural dwellers. As the result of ongoing research in the field of microfinance, we now have a better sense of the elements required for a basic financial service to meet the needs of unbanked people, and in that sense, to be transformational.

Rural, branchless banking has increasingly become the solution for rural areas in the developing world. The service is typically based on a business correspondent model, in which a person (or agent) who works for a microfinance institution (MFI) serves specific villages, which he visits on a frequent basis. The agent will act as an enabler of financial transactions by actively recording and honoring the transactions themselves. A range of services are provided, such as cash deposits, loans provision, loan repayment etc. While these services have been available for a few years in countries such as India, Bangladesh and Kenya, the market is now trying to scale in order to maximize the opportunity, enable more people to benefit from the financial services and thereby improve their economic situation. The main obstacle to progress is the lack of scalable identity solutions that can allow various services to be provided securely.

\subsection{Rural Women Banking By Mobile Phone- Zimbabwe}

The system is fairly simple [8]. A user registers for mobile phone banking with their service provider and is given a mobile "e-wallet" - an application on their SIM card that is linked to their phone number. When the user wants to pay for services or transfer money to someone they simply have to go to an agent and pay the desired amount, which is loaded onto the "e-wallet". The payment is made and the recipient can withdraw the money from an agent. There are various agents affiliated with the mobile service providers across the country, making the service easily accessible to those in rural areas. It is a convenient system that no longer limits the women's movements.

The model is borrowed from Kenya's pioneering M-Pesa, which has experienced phenomenal growth from 20,000 users at its launch in 2007 to an estimated 14 million this year. Moyo a member of Nare's money club said that in the past women had to gather under a tree to make physical contributions [8]. Now, the convenience of mobile transfers means 'they can co-ordinate their contributions without concerns about distance'. While money transfer services sprouted across the country in the aftermath of the mass exodus of Zimbabweans to work all over the world, the "bureaux de change" remained in the cities. So those in the rural areas were forced to rely on undependable and expensive cross-border transporters who demand up to 20 percent of the total amount being sent.

\section{Research Methodology}

The research undertook a case study of Gwanda District. The study concentrated primarily on Gwanda District, targeting rural residents at Renkin Terminus boarding buses to different rural locations in Gwanda District. The study also involved interacting with banks which serve the Gwanda community. Data was collected through interviews, observations, questionnaires and documentation.

\subsection{Population}

The assessment was carried out in Gwanda District where several banks which serve the rural residents were given questionnaires and bank officials were interviewed: ZB bank, CBZ, Royal bank, CABS and, POSB, mobile operators; Econet through its agent Zimpost and the central bank; Reserve bank of Zimbabwe. Due to time and financial constraints, the commercial banks that were surveyed are in Gwanda town and hence the population under assessment was confined to one town to represent all the other branches since the study

\footnotetext{
${ }^{2}$ Prasad S, 2010: Mobile banking yet to take off in rural India, http://www.zdnet.com/mobile-banking-yet-totake-off-in-rural-india-2062202064/ viewed on 08 April 2013
} 
focuses on a case study serve for RBZ located in Bulawayo. The targeted population consisted of operations managers, supervisors and employees in both the front and back offices. It also consisted of farmers from Magwe irrigation scheme, Thuli institute of farmers, as well as the traditional man on the streets at Renkin bus terminus in Gwanda.

\subsection{Sample Size}

A total of 37 respondents were used. Composition of the study is as follows:

Table 1: Sample size

\begin{tabular}{|l|l|}
\hline Groups under study & No. of Respondents \\
\hline Banks & 5 \\
\hline Mobile operators & 1 \\
\hline Reserve Bank of Zimbabwe & 1 \\
\hline Rural residents (unbanked population) & 30 \\
\hline
\end{tabular}

Source: Primary data

\subsection{Sampling Method}

A non-probability sampling technique was employed in this study. Convenience sampling was adopted for the study because it was a cheaper and quicker method to obtain data from the rural residents. Purposive sampling in financial institutions under study was adopted to obtain some specific results from key informants and this was done by targeting individuals in the front office who deal mainly with the rural residents, that is those at the enquiries desks of banks, retail managers and tellers.

\subsection{Stratified Random Sampling}

In probability sampling, each element in the population has a known and equal probability of selection. Stratified sampling enables better understanding of the constituents of the universe and stratification makes it possible to use different sampling designs in each stratum. Furthermore dividing the population into a series of relevant strata enhances data integrity and it may minimize the chances of inappropriate data. The researchers divided the research population into four strata, that is, rural residents, Gwanda banks, mobile operators and central bank.

\subsection{Data Collection Instruments}

The research used self-administered questionnaires as the central mechanism through which primary data was collected. The questions contained in the questionnaire were mainly checklist and open ended questions. The researchers also made use of personal interviews in the collection of data. These interviews were conducted to compliment questionnaires sent.

\subsection{Interviews}

The interview used was the face to face interview as the managers were too busy to read the questionnaires. They preferred to be asked in person as they felt that some of the questions were not applicable and a time frame of 30 minutes was given per interview. These interviews were quite fruitful as they were able to clear some questions raised that were not clear from the answers obtained from questionnaires and from the managers who thought the questions asked were not applicable. Surprisingly, that is where vast information came from, hence these interviews shaded some light on some of the questions that were raised. Interviews were done at Zimpost with the manager and at RBZ with the IT personnel as well as ZABG.

The researcher used Microsoft Excel. Data is presented in the form of tables and graphs.

The targeted population was mainly the front office staff or retail staff who deal mainly with clients on a daily basis and communicate with them on a face to face level. The response rate was quite desirable as the researcher arrived when business was slow and some of the retailers answered the questions instantly, others after 2 hours but to a maximum of a day. Only one manager asked for an interview (face to face) partly because he thought Zimpost did not offer any e-banking technique when it did and partly because he wanted clarification and explanations. The majority of rural residents responded inside the buses because the researcher thought it was the only convenient way to approach them as they will be boarding to different areas. Individuals targeted mostly included farmers working and residing in Magwe Irrigation and Thuli institute. 


\section{Empirical Results}

The following table illustrates the response gathered from the targeted respondents of the study.

Table 2: Response rate from Targeted respondents

\begin{tabular}{|l|l|l|}
\hline Targeted Respondents & Total Number Sent & Actual Response Rate \\
\hline Supervisors/Retailers & 5 & 4 \\
\hline E-banking Managers/Officers & 1 & 1 \\
\hline Interviews (face to face) & 2 & 2 \\
\hline ICTs Personnel & 1 & 1 \\
\hline $\begin{array}{l}\text { Rural Residents at Gwanda } \\
\text { Renkin Terminus }\end{array}$ & 40 & 30 \\
\hline Total & $\mathbf{4 9}$ & $\mathbf{3 7}$ \\
\hline
\end{tabular}

Source: Primary data

There are various tools used by different banks in Gwanda and these depends on the level of adoption by that bank and its effective use in trying to capture the interests of the rebellious bank customers, the unbanked and the banked but ignorant clients. The researcher discovered some tools that he was not aware of but that are widely used by irrigation farmers in Gwanda for example money order transfers which replaced the traditionally used telegram. Eco-cash is at the uppermost (41percent) of the ladder as its outreach covers a wide spectrum and it has about 18 agents who have branches in different parts of Gwanda. Econet Wireless Zimbabwe's Eco-Cash allows money transfers without having to use bank accounts, but it uses the cell-phone and registered dealers where recipients of cash would go to deposit or redeem cash. The following figure represents the percentage usage of various e-banking tools mostly used by customers in Gwanda;

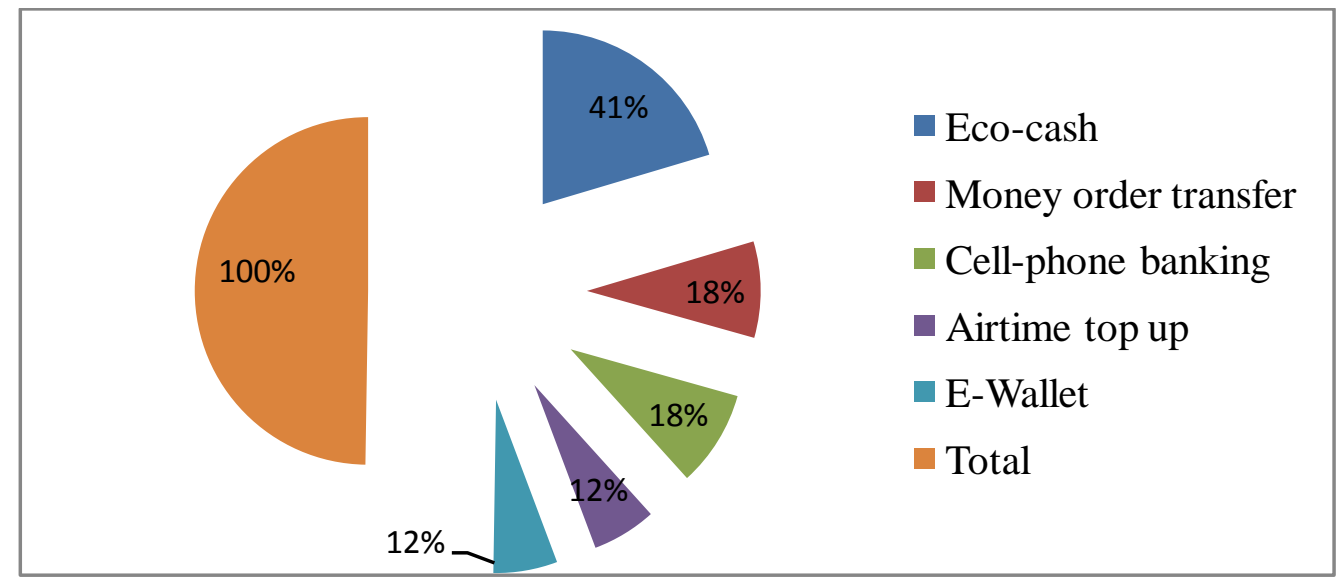

Figure 1: E-banking facilities and their percentage usage in Gwanda, Source: Primary data

From Figure 1 above the respondents who use the e-banking tools listed above are 17 out of the total of 30 respondents who were able to respond back.

\subsection{Contribution of E-Banking on Rural Development}

The adoption rate of e-banking services by clients is increasing at a decreasing rate. Clients only need to be taught on how these services work and how fast, quick and convenient they are in transactional activities. Mobile phones are providing Zimbabwe with an opportunity to leapfrog development stages in the country and many Zimbabweans' first experience of the internet is through the mobile phone. Unlike a decade ago, today it is very easy to secure a mobile phone and SIM-card prices have fallen drastically. Mobile phones used to be a preserve of the rich elite, but now more low-income Zimbabweans, in both rural and urban areas, have access to them. The arrival of cheap, Chinese-made products, such as G-Tide, have taken Zimbabwe by storm as mobile users snap them up for half the price of leading brands like Nokia and Samsung. Econet Wireless Zimbabwe's Eco-Cash allows money transfers without having to use bank accounts, but it uses the cellphone and registered dealers where recipients of cash would go to deposit or redeem cash thus making it easy since the majority own mobile phones. The following table highlights the ratio of individuals who have mobile phones to the ones who do not have. 
Table 3: Mobile phone users

\begin{tabular}{|l|l|l|}
\hline Mobile users & Frequency & Mobile phone users (\%) \\
\hline Have a cellphone & 25 & 83 \\
\hline Do not have & 5 & 17 \\
\hline Total & $\mathbf{3 0}$ & $\mathbf{1 0 0}$ \\
\hline
\end{tabular}

Source: Primary source

The table above demonstrates the increasing levels at which individuals have access to mobile communications and are thus likely to use e-banking facilities at higher rates than they would resort to brick and mortar structures which are seen as distant from economic agents. This shows evidence why airtime top-up is used by almost all banks in Gwanda since the majority of individuals own cell phones. The launch by banks to offer rural banking services program is to enable rural areas to have access to banking facilities. In some instances rural residents travelled distances of at least $100 \mathrm{~km}$ to reach the nearest banking port, making it highly probable those economic agents would retain cash in their granaries. Modernizing banks aim to close the great divide between the poor as well as the marginalized and the urbanites as a milestone toward economic development and empowerment of the rural communities.

E-banking services have a potential of increasing the impact of education interventions for example through e-learning. The majority of respondents (about 47 percent) did Ordinary Level education meaning the residents are legible, that is, they can read and write since they are also able to use a cellular phone. Computer functions are almost the same as mobile phones meaning it will not be a hard problem teaching them on how to use them. Funded mainly through a levy and contributions from Government and its partners, the Rural Electrification Agency (REA) in Gwanda has electrified institutions such as schools, clinics, mines and government extension offices, community irrigation schemes such as Magwe and resettlement areas.

\subsection{Effectiveness of E-Banking on Agro Business Activities}

The target population was partly from the irrigation schemes in Gwanda, mainly from Thuli institute and Magwe irrigation. Farmers mainly save money at Zimpost and they mostly use either money order transfers or Ecocash in transacting on a weekly or monthly basis. Zimpost has a database of clients and knows their behavioral tendencies making it easy for a microfinance institution that might want to advance loans to this group into their portfolio. They can therefore, make use of money order transfers, Eco-cash, cell-phone banking for notifications and reminders or any other e-banking facility to make a payment. This makes it easy for farmers to obtain loans to use in order to meet their day to day expenditures should a need arise.

\subsection{Tests for Hypothesis}

$\mathrm{H}_{0}$-E-banking is effective in catering for the 'unbanked' individuals in rural areas.

$\mathrm{H}_{1}$-E-banking is ineffective in catering for the 'unbanked' individuals in rural areas.

The percentage of the unbanked is estimated to be 70 percent- according to statistics from the central bank. From the findings of this study in Gwanda about 17 out of a sample population of 30 rural residents use ebanking services and they did not have any bank accounts meaning they were considered as the unbanked. To calculate the percentage of the incorporated individuals into the banking sector, we divide the e-banking users by the total sample population, and then multiply by percentage of the unbanked population. This is illustrated by Table below:

Table 4: Effects of e-banking use on percentage of the unbanked

\begin{tabular}{|l|l|l|}
\hline \multicolumn{2}{|l|}{ Banked /Unbanked } & Effect \\
\hline Banked through use of e-banking & 17 & $39.7 \%$ \\
\hline Unbanked & 13 & $30.3 \%$ \\
\hline Total sample & 30 & \\
\hline & & \\
\hline Total unbanked & & $\mathbf{7 0 \%}$ \\
\hline
\end{tabular}

\section{Source: Primary data}

The data above shows a reduction of about 39.7 percent of the unbanked into the banked population through use of different e-banking services by rural residents. Basing on the results from Gwanda District, the number of the unbanked individuals is reduced from 70 percent to 30.3 percent. Thus, it can be concluded that effective use of e-banking facilities by the unbanked population promotes financial inclusion and serves as a strategic tool in banking the unbanked population. 


\section{Conclusion}

This study concludes that in order to sufficiently offer mobile banking services, it is necessary for banks and mobile networks to open different branches in the form of agents like what ECONET has done. Productivity increases as the bank extends its geographic reach through e-banking services. There is also need for the creation of money earning opportunities, for example, by operating a mobile phone booth in order to accommodate those individuals who do not have phones but have relatives in South Africa who want to send money to them. Through positive word of mouth, in general talk with residents, the study discovered that individuals who do not own phones pay a certain fee for receiving and replying messages to those who are privileged and own a mobile phone. Thus, banks may earn excess clients by bringing those mobile booths to the exposure of unbanked members thereby addressing the issue of financial exclusion.

\section{References}

[1]. Barnes D. and Corbitt B. 2003, ICT adoption and use in the UK SME'S: a failure of initiatives, Electronic Journal of Information Systems Evaluation, Vol. 2 No. 2, pp.91-96

[2]. Dube T, Chitura T, and Runyowa L, Adoption and Use of Internet Banking in Zimbabwe: An Exploratory Study, Journal of Internet Banking and Commerce, April 2009, Vol. 14, No. 1, pp. 1-12

[3]. Georpott, L, Kornmeirer, C, 2009, E-Banking Development and Applications, Current Issues and Challenges, Georgia College, USA.

[4]. Scornavacca, S. S and Hoehle, D, 2007, Effects of Perceived Risks on Adoption of Internet Banking Services: An Empirical Investigation in Taiwan, viewed on 26 March 2013 at < www.csulb.edu/web/journals/jecr/issues/20122/paper1.pdf>

[5]. Porteous , D, 2006, The enabling environment for mobile banking in Africa, viewed May 2006, 〈http://www.bankablefrontier.com>

[6]. Biriwasha, K, M, 2011, Mobile money arrives in Zimbabwe, viewed on 31 June 2011, <http://ziviso.wordpress.com>.

[7]. Lufumpa, C L, Ncube, M, Ndikumana, L, 2010. Mobile Banking in Africa: Taking the Bank to the People, African Economic Brief vol.1, issue 8

[8]. Nare, T, 2011, Rural Women Banking by Mobile Phone, www.allafrica.com/stories/201111141581.html viewed 15 November 2011. 